\title{
Chemical Composition and Physical Properties of Some Egyptian Cucurbitaceae Seeds and Oils
}

\author{
Shalaby, H.G.F. ${ }^{1}$, S.A. Elsohaimy ${ }^{2,3}$, A.A. Zeitoun ${ }^{1}$, M.A.M. Zeitoun ${ }^{1}$ \\ 1 Food Science Department, Faculty of Agriculture (Saba Basha), Alexandria \\ University, Alexandria, Egypt \\ ${ }^{2}$ Food Technology Department, Arid Lands Cultivation Research Institute, the City of \\ Scientific Research and Technological Applications, Alexandria, Egypt \\ ${ }^{3}$ Department of Technology and Organization of Public Catering, Institute of Sport \\ Tourism and Service
}

\begin{abstract}
The current study was intended to evaluate the chemical composition, functional properties, and physical properties of some cucurbits seed. Chemical composition, functional properties of sweet melon (Cucumis melo var. reticulatus), sweet melon (Cucumis melo var. aegyptiacus) watermelon (Citrullus lanatus), citron melon (Citrullus lanatus var. Colocynthoides). Pumpkin (Cucurbita maxima), and summer squash (Cucurbita pepo), were studied as well as the characteristics of their seed oils. The seeds are rich in protein, crude fat, and crude fiber. The seeds contained high amounts of $\mathrm{K}, \mathrm{Mg}, \mathrm{Na}, \mathrm{Fe}$, and $\mathrm{Mn}$. Water and fat absorption capacities, emulsification properties, and foam stability were fairly good in all seeds. Data obtained for the oils' characteristics agree well with those of other edible vegetable oils. The obtained results revealed that the seeds presented an alternative source of vegetable oil. Seeds could be added to food systems such as bakery products.
\end{abstract}

Keywords: Cucurbitaceae seeds, chemical composition, functional properties, oil, and fatty acids

\section{INTRODUCTION}

Cucurbitaceae family (gourd family) encompasses several edible plants belonging to the genera Cucurbita, Citrullus, Cucumis, Momordica, Benincasa, and Luffa, (Kaushik et al., 2015). These fruits and vegetables include pumpkin, winter melon, squash, zucchini, watermelon, cucumber, bitter melon, ribbed gourd, luffa, etc. Most of the plants have been cultivated for human consumption for ages. The young stems, leaves, flowers of some plants in this family, and most fruits (pepo) are culinary articles. The fleshy fruits are used for salad (cucumber, watermelon), stir-fry (squash, zucchini, bitter melon), curry (pumpkin), pie (pumpkin), and pasta (zucchini) among a myriad of other uses (Gong et al., 2012). Many Cucurbitaceae produce seeds that were rich in oil and protein. Although none of these oils has been utilized on an industrial scale, many are used as cooking oil in some countries in Africa and the Middle East (Sawaya et al., 1983). Pumpkin and melon seeds contain $23-55 \%$ oil and $23-$ $35 \%$ protein. The fruits of these plants constitute an important source of human and animal feed and simultaneously contain significant amounts of seeds. Melon seeds are utilized for oil production, especially in Nigeria (Girgis and Said, 1968) The processing of fruits and vegetables can result in large quantities of waste materials and by-products such as peels and seeds. These by-product materials may cause a serious environmental problem (da Silva and Jorge, 2014). 
Due to the increasing consumers' request for plant oils, finding novel raw materials is shape one of the key factors for improving the oil industry and profitability. Introducing new seed oil to the consumer, with high nutritional values and health-promoting advantages would be considered as one of the important defies for both the oil industry and food technology. Various studies have been lately focused on studying the properties of many vegetable and fruit seed oils as a novel source of edible oil as well as explaining their appealing nutritional values. These seeds are considered as a by-product or waste such as Watermelon seeds, pumpkin seeds, and gurum seeds (Karrar et al., 2020). In recent years, fruit seeds have received growing interest due to the nutritional and medicinal properties of their bioactive components. Hence, fruit seeds can be used for the extraction of plant oils, which contain a great number of valuable bioactive components and natural antioxidants (Rezig et al., 2019).

Melon (Cucumis melo L.) belongs to the Cucurbitaceae family which is a medium-sized plant family found in warm regions of the world. Melon presents a high potential for consumption due to the exceptional taste of the flesh. During the processing of melon fruit for juice or concentrate, large quantities of by-products are generated. Much of these materials are composed of melon seeds which are generally discarded. The amount of melon seeds recovered from the fruit processing industry has been estimated to 738 thousand tons, based on the data of fruit production (FAOSTAT, 2015). They are usually dried and used to add flavor to Indian dishes and desserts (Maran and Priya, 2015). Melon seeds are also a good source of natural antioxidants and may serve as food ingredients for maintaining shelf life (Zeb, 2016). Melon seeds were found to contain (on a dry weight basis): moisture (7.16\%), oil $(30.65 \%)$, protein $(27.41 \%)$, ash $(4.83 \%)$, carbohydrate $(29.96 \%)$, fibers $(25.32 \%)$, and considerable amounts of antioxidant substances as phenolic compounds (Mallek-Ayadi et al., 2018). Melon seeds are excellent sources of protein and oil and they are utilized directly for human consumption as snacks after salting and roasting in Arabian countries (Al-Khalifa, 1996).

Watermelon (Citrullus lanatus) is one of the major underutilized fruits grown in the warmer part of the world. The juice or pulp from watermelon is used for human consumption while rind and seeds are major solid wastes (Bawa and Bains, 1977). The rind is utilized for products such as pickles and preserves as well as for pectin extraction (Hasan, 1993). whereas seeds are a potential source of protein (Kamel et al., 1985) and lipids (El-Adawy and Taha, 2001a).

Therefore, the present work aimed to evaluate the chemical composition and functional properties of some Cucurbitaceae seeds. 


\section{MATERIALS AND METHODS}

\section{Materials}

\section{Plant materials}

Mature fruits of watermelon (Citrullus lanatus), Pumpkin (Cucurbita maxima), summer squash (Cucurbita pepo), citron melon (Citrullus lanatusvar. Colocynthoides), sweet melon (Cucumis melo var. reticulatus), and sweet melon (Cucumis melo var. aegyptiacus) were obtained during the summer season from a private farm located in Beheira Governorate, Egypt.

\section{Chemicals and reagents:}

Solvents, chemicals, and reagents were obtained from El-Gomhouria for chemicals Company, Alexandria, Egypt, and Sigma-Aldrich (Steinheim, Germany). All chemicals and reagents used were of analytical grade.

\section{Preparation of plant samples:}

The fruits were immediately peeled and seeds were carefully separated by hand from the pulp, cleaned and washed off any adhering residue, Then, damaged seeds were removed, and the remaining sound seeds were ovendried at $40^{\circ} \mathrm{C}$ for $24 \mathrm{~h}$. Dried seeds were ground to powder form, The seed powder was preserved in hermetic bags at $-20^{\circ} \mathrm{C}$ until analysis.

\section{ANALYTICAL METHODS \\ Chemical composition: \\ Moisture content:}

The moisture content of watermelon, pumpkin, summer squash, citron melon, sweet melon Cucumis melo var. reticulatus, and sweet melon Cucumis melo var. aegyptiacus seeds were determined in an oven-dried at $105^{\circ} \mathrm{C}$ to constant weight as described in (Horwitz and Albert, 2006). the results are expressed in percentages.

\section{Fat content}

The fat content of the grounded seed powder was determined using a Soxhlet extraction apparatus with hexane for $8 \mathrm{~h}$ (Carrapiso and García, 2000). The solvent was then removed using a rotary evaporator under reduced pressure at $40^{\circ} \mathrm{C}$.

\section{Protein content}

The total protein of seeds was determined by the Kjeldahl method (AOAC, 2000). Protein was calculated using the general factor (6.25) (Ortiz et al., 2006). Data were expressed as percentages of dry weight.

\section{Dietary fiber}

The value was obtained by subjecting the sample to digestion with boiling acid and alkali solutions, the organic residue (crude fiber) was determined using Ankom fiber analyzer (Model A200I, Serial \# A220220463), according to (Horwitz and Albert, 2006). 


\section{Ash content}

Ash content was determined by ashing the sample at $600^{\circ} \mathrm{C}$ for $2 \mathrm{hr}$. Analyses were performed according to (Horwitz and Albert, 2006)

\section{Carbohydrate content}

Carbohydrate content of the melon seeds powder was estimated by the difference of mean values: 100-(sum of moisture, ash, protein, and lipids\%) (Lima et al., 2014)

\section{Determination of minerals content}

The sample was digested according to methods of (AOAC, 2000). Whole Cucurbitaceae seeds flour $(0.5 \mathrm{~g})$ was weighed and ashing in muffle at $550^{\circ} \mathrm{C}$ for 2 hours. Then the ashes were dissolved with $100 \mathrm{~mL}$ of $1 \mathrm{M} \mathrm{HCl}$, then filtration by Wattman (No 1). Dissolved ash was analyzed for iron, magnesium, potassium, sodium, zinc, manganese, copper, and calcium contents by using Inductively Coupled Plasma- Mass Spectrometer (ICP/MS), NEXION 300X series was used to determine these minerals $(\mathrm{mg} / 100 \mathrm{~g})$. Argon gas was used for excitation of the element atom (Nardi et al., 2009)

\section{Cold extraction of crude fat}

Fifty grams of ground seeds were placed in a dark flask (capacity $=1 \mathrm{~L}$ ), homogenized with hexane $(1: 5, \mathrm{w} / \mathrm{v})$, and shaken for $4 \mathrm{hrs}$. The mixture was centrifuged for $15 \mathrm{~min}$ at $1000 \times \mathrm{g}$. The supernatant was then filtered through a filtering paper (Whatman No. 2). The extraction procedure was repeated twice. The solvent was removed using a rotary evaporator at $40^{\circ} \mathrm{C}$. The obtained oil was dried under a stream of nitrogen and stored at $-20^{\circ} \mathrm{C}$ in amber glass flasks until analyses(Mallek-Ayadi et al., 2018).

\section{Physicochemical Characterization of Oils.}

Refractive index (using an Abbe` refractometer at $25^{\circ} \mathrm{C}$ ), free fatty acids (Method $\mathrm{Ca} 5 \mathrm{a}-40$ ), acid value (Method $\mathrm{Cd} 3 \mathrm{a}-63$ ), peroxide value (Method $\mathrm{Cd}$ 8-53), saponification value (Method Cd 3-25), and iodine value (Method Cd 125 ) of the oil samples were determined according to AOCS methods (Walker, 1980).

\section{Determination of functional properties}

The Bulk density, water holding capacity, oil holding capacity, Foam capacity, Emulsion capacity, and stability measurements were performed for Cucurbitaceae seeds powders. All samples were milled and sifted through a 1 $\mathrm{mm}$ mesh screen.

\section{Bulk density measurement}

A previously tarred $10 \mathrm{~mL}$ graduated cylinder was gently filled with the melon-seed powder sample. The bottom of the cylinder was then softly tapped on a laboratory bench several times until there was no further reduction of the height of the sample in the cylinder. Bulk density was expressed as weight per unit of volume of seed powder $\left(\mathrm{g} \mathrm{mL}^{-1}\right)$. (Kaur and Singh, 2005) 


\section{Water holding capacity}

The water retention capacity was measured following the method of (Garau et al., 2007)). Ground samples of seeds $( \pm 0.5 \mathrm{~g})$ were hydrated in excess water during $24 \mathrm{hr}$. in a $50 \mathrm{ml}$ tube, before centrifugation at $2000 \times \mathrm{g}$ for $25 \mathrm{~min}$. The excess supernatant was decanted. Water retention was recorded in terms of $g$ water/g dry sample.

\section{Oil holding capacity}

The oil retention capacity was conducted according to (Garau et al., 2007) method. Ground samples of melon seeds $( \pm 0.5 \mathrm{~g})$ were mixed with sunflower oil $(10 \mathrm{~mL})$, then centrifuged at $2000 \times \mathrm{g}$ for twenty minutes and the excess supernatant was decanted. Oil retention capacity was expressed as $\mathrm{g}$ oil/g dry sample.

\section{Emulsion capacity (EC)}

Ten milliliters distilled water, $10 \mathrm{ml}$ sunflower oil, and $1 \mathrm{~g}$ flour sample was prepared and mixed for $1 \mathrm{~min}$ using a Moulinex homogenizer (Organotechnie, Courneuve, France) to obtain an emulsion. The emulsion was centrifuged at $2000 \times g$ for $5 \mathrm{~min}$. The ratio of the height of the emulsion layer to the total height of the mixture was calculated as emulsion capacity, expressed as a percentage. (Yasumatsu et al., 1972)

\section{Foam capacity (FC)}

Foaming capacity was examined according to the Narayana and Narsinga Rao (1982) procedure with a slight modification. First, $1 \mathrm{~g}$ of flour sample was added to $50 \mathrm{~mL}$ distilled water. Then, the suspension was mixed and shaken for 5 min using the Moulinex homogenizer to incorporate air. After that, whipped samples were immediately transferred into a graduated cylinder. Foaming capacity was calculated as the percentage increase in the volume of the sample after whipping. The total volume remaining at interval of $15,30,45$ and 60 minutes was noted for the study of foaming stability. The following formula was used:

$$
\% \mathrm{FC}=\frac{\text { the volume of foam AW }- \text { volume of foam BW }}{\text { the volume of foam BW }} * 100
$$

where $\mathrm{AW}=$ after whipping and BW = before whipping. (Narayana and Narasinga Rao, 1982)

While foam stability was calculated according to the following equation:

Foam stability $(\%)=$ ( foam volume after time $(\mathrm{t}) /$ Initial foam volume) $\mathrm{X}$ 100

\section{Statistical analysis}

The average contents of proximate analysis, mineral composition, oil properties, functional properties were reported as mean \pm standard deviation (SD), $(n=3)$. Using SPSS for Windows 16.0. 


\section{RESULTS AND DISCUSSION \\ Chemical characteristics of Cucurbitaceae seeds Proximate Composition of Cucurbitaceae Seeds}

Chemical analysis of the seed's samples; (sweet melon Cucumis melo var. reticulatust, Cucumis melo var. aegyptiacus, watermelon Citrullus lanatus, Citrullus lanatus var. Colocynthoides, Pumpkin Cucurbita maxima, and summer squash Cucurbita pepo were shown in Table 1. The obtained results showed a relatively high content of crude fat ranged from (27.3 to $39.1 \%$ ), crude fiber ranged from (12 to $29 \%$ ), protein ranged from (20.1 to $40.1 \%$ ), ash ranged from (2.3 to $4.3 \%)$. Pumpkin showed the highest content of protein $(40.1 \pm 0.32 \%)$ and ash $(4.3 \pm 0.71 \%)$, while summer squash showed the highest content in crude fat $(39.1 \pm 0.12 \%)$. At the same time, the highest content of crude fiber was noted with citron melon. The differences in the nutritional parameters might be due to the differences in species, varieties, ripening stages, fertilization system, and growing conditions. The results of the present study agreed with (Mallek-Ayadi et al., 2018) who reported that the Cucumis melo contained $11.2 \%$ moisture, 13.5-22 \% crude protein, and (Elinge et al., 2012) who reported that pumpkin contained 5\% moisture, 38\% fat, protein 27.48\%, however higher than (Gohari et al., 2011) summer squash Cucurbita pepo contained $5.2 \%$ moisture, $41 \%$ fat, $25 \%$ protein, and ash 5.3\% Also, (da Cunha et al., 2020) reported that Cucumis melo var. reticulatust seeds flour contain $17.6 \%$ crude protein $30.4 \%$ fat, ash content 4.12 and carbohydrate about (9.7\%). On the other hand, the obtained values lower than that showed by (Oluwadare et al., 2008) where is the watermelon Citrullus lanatus contained $26.3 \%$ protein, $43.1 \%$ fat, $3.8 \%$ ash. However, higher than that reported by (Riaz et al., 2015) who reported that Citrullus lanatus var. Colocynthoides contained $6.4 \%$ moisture, $28.5 \%$ fat, $13.9 \%$ protein, and ash $2.23 \%$. The obtained results in the current study emphasized the high nutritional quality of the investigated seed as a good source of protein, fat and fiber which is encourage their utilization in food applications. 
Table (1): Proximate composition ( $\mathrm{g} / \mathbf{1 0 0 g}$ ) of some cucurbit's seeds (on a dry weight basis)

\begin{tabular}{|c|c|c|c|c|c|c|}
\hline \multirow{2}{*}{ Components (\%) } & \multicolumn{6}{|c|}{ Cucurbits seeds } \\
\hline & sweet melon ${ }^{*}$ & sweet melon $2^{* *}$ & watermelon & citron melon & Pumpkin & summer squash \\
\hline Moisture & $5.8 \pm 0.09^{e}$ & $6.1 \pm 0.59^{d}$ & $6.5 \pm 0.07^{b}$ & $6.4 \pm 0.04^{c}$ & $6.75 \pm 0.81^{a}$ & $5.6 \pm 0.05^{f}$ \\
\hline Protein & $24.6 \pm 0.50^{d}$ & $25.0 \pm 0.60^{c}$ & $20.1 \pm 0.83^{f}$ & $21.0 \pm 0.56^{\mathrm{e}}$ & $40.1 \pm 0.32^{a}$ & $34.4 \pm 0.23^{b}$ \\
\hline Crude fat & $31.8 \pm 0.45^{d}$ & $32.5 \pm 0.09^{c}$ & $33.5 \pm 0.25^{b}$ & $27.3 \pm 0.61^{f}$ & $28.3 \pm 0.02^{e}$ & $39.1 \pm 0.12^{a}$ \\
\hline Crude fiber & $26.0 \pm 0.08^{b c}$ & $24.0 \pm 0.09^{c}$ & $28.0 \pm 0.33^{\mathrm{ab}}$ & $29.0 \pm 0.25^{\mathrm{a}}$ & $16.0 \pm 0.20^{d}$ & $12.0 \pm 0.34^{e}$ \\
\hline Ash & $3.8 \pm 0.35^{b}$ & $3.3 \pm 0.21^{c}$ & $3.0 \pm 0.14^{\mathrm{e}}$ & $2.3 \pm 0.21^{f}$ & $4.3 \pm 0.71^{a}$ & $3.1 \pm 0.63^{d}$ \\
\hline Carbohydrate $^{*}$ & $8.0 \pm 0.41^{d}$ & $9.1 \pm 0.31^{b}$ & $9.0 \pm 0.32^{c}$ & $14.0 \pm 0.35^{a}$ & $4.55 \pm 0.09^{f}$ & $5.8 \pm 0.37^{\mathrm{e}}$ \\
\hline
\end{tabular}

*The values in the table are means of the triplicates \pm SD

* sweet melon 1 Cucumis melo var. reticulatus

** sweet melon 2 Cucumis melo var. aegyptiacus

A carbohydrate is calculated by difference. 


\section{Minerals content}

The minerals content of cucurbits seeds powder is presented in (Table 2) and showed a high content of minerals in the studied seeds. Potassium content ranged from (456.44 to $690.12 \mathrm{mg} / 100 \mathrm{~g}$ ), magnesium (138.12 to 385.21 $\mathrm{mg} / 100 \mathrm{~g}$ ), calcium (96.56 to $249.18 \mathrm{mg} / 100 \mathrm{~g}$ ), sodium (138.63 to 276.81 $\mathrm{mg} / 100 \mathrm{~g}$ ), iron (11.88 to $16.86 \mathrm{mg} / 100 \mathrm{~g})$, manganese $(7.13$ to $15.5 \mathrm{mg} / 100 \mathrm{~g}$ ), zinc (2.97 to $6.07 \mathrm{mg} / 100 \mathrm{~g}$ ), copper (2.44 to $3.94 \mathrm{mg} / 100 \mathrm{~g})$. The highest content of potassium, iron, calcium, and manganese was remarked for sweet melon Cucumis melo var. reticulatust (690.12, 16.86, 249.18, and 15.50 $\mathrm{mg} / 100 \mathrm{~g}$ ) respectively. The highest content of magnesium was noted in summer squash (385.21 mg/100g). Cucumis melo var. aegyptiacus showed the highest content of sodium $(276.81 \mathrm{mg} / 100 \mathrm{~g})$. On the other hand, pumpkin showed the highest content of zinc $(6.07 \mathrm{mg} / 100 \mathrm{~g})$, and Cucumis melo var. reticulatust showed the highest content in copper $3.94 \mathrm{mg} / 100 \mathrm{~g}$ ). The mineral contents vary according to the plant species and varieties.

The result presented in the current investigation are lower than the previous study by Mallek-Ayadi, et al., (2018), who reported that sweet melon seeds contain Potassium (1148.75 $\pm 1.53 \mathrm{mg} / 100 \mathrm{~g})$ Magnesium (1062.25 \pm $0.72 \mathrm{mg} / 100 \mathrm{~g}$ ) Calcium (506.13 $\pm 1.52 \mathrm{mg} / 100 \mathrm{~g})$ Sodium (336.5 \pm 0.72 $\mathrm{mg} / 100 \mathrm{~g})$ but higher in Iron $(2.69 \pm 0.81 \mathrm{mg} / 100 \mathrm{~g})$ Zinc $(2.34 \pm 0.64 \mathrm{mg} / 100 \mathrm{~g})$ Manganese $(1.25 \pm 0.15 \mathrm{mg} / 100 \mathrm{~g})$ Copper $(0.53 \pm 0.12 \mathrm{mg} / 100 \mathrm{~g})$, also Da Cunha et al., (2020) reported that the occurrence of potassium (957 mg/100 g), and magnesium (504 $\mathrm{mg} / 100 \mathrm{~g}$ ). While higher than the result reported by (Gwana et al., 2014) who reported that watermelon Citrullus lanatus seeds contain calcium (1472.8 mg/100g), magnesium (1511.15 mg/100g), sodium (2520.0 mg/100g), potassium (3187.0 mg/100g), iron (90.0 mg/100g), and zinc (37.03 $\mathrm{mg} / 100 \mathrm{gm}) \mathrm{mg} / \mathrm{kg}$. While (Riaz et al., 2015) reported that citrullus lanatusvar. Colocynthoides, contained calcium (130.78 mg/100gm), magnesium (89.5), potassium (123.21), iron (43.3), and zinc (10.05) ppm in Pumpkin cucurbita maxima. Those results are higher than that reported by (Eltayebl and Babiker, 2008) who reported that pumpkin contained (152.5 mg/100g) potassium, (5.34 mg/100g) magnesium, (35.5 mg/100g) sodium, and (23.9 $\mathrm{mg} / 100 \mathrm{~g}$ ) iron, while (Elinge et al., 2012) who reported that cucurbita pepo contains calcium $(9.7 \mathrm{mg} / 100 \mathrm{~g})$, magnesium $(67.41 \mathrm{mg} / 100 \mathrm{~g})$, potassium $(237.24 \mathrm{mg} / 100 \mathrm{~g})$, sodium $(170.35 \mathrm{mg} / 100 \mathrm{~g})$. The findings in the current study revealing the significant content of essential minerals such as $\mathrm{K}, \mathrm{Mg}, \mathrm{Na}, \mathrm{Fe}$ and $\mathrm{Mn}$ in the cucurbit's seeds which may be useful for improving human health and might be applicable in health-promoting foods. 
Table (2): Minerals composition ( $\mathrm{mg} / \mathbf{1 0 0 \mathrm { g } )}$ of cucurbits seeds (on a dry weight basis)

\begin{tabular}{|c|c|c|c|c|c|c|}
\hline \multirow{2}{*}{$\begin{array}{c}\text { Mineral } \\
(\mathrm{mg} / 100 \mathrm{gm})\end{array}$} & \multicolumn{6}{|c|}{ Cucurbits seeds } \\
\hline & sweet melon $1^{*}$ & sweet melon $2^{\star *}$ & watermelon & citron melon & Pumpkin & summer squash \\
\hline Potassium (K) & $690.12^{\mathrm{a}}$ & $564.39^{d}$ & $524.17^{\mathrm{e}}$ & $456.44^{f}$ & $608.54^{c}$ & $612.32^{b}$ \\
\hline Magnesium (Mg) & $298.56^{c}$ & $270.61^{d}$ & $200.26^{\mathrm{e}}$ & $138.12^{f}$ & $328.21^{b}$ & $385.21^{\mathrm{a}}$ \\
\hline Sodium (Na) & $253.43^{c}$ & $281.4^{a}$ & $246.8^{d}$ & $138.63^{f}$ & $276.81^{b}$ & $241.25^{\mathrm{e}}$ \\
\hline Calcium (Ca) & $249.18^{a}$ & $116.93^{c}$ & $122.80^{b}$ & $96.56^{\dagger}$ & $98.26^{\mathrm{e}}$ & $104.78^{d}$ \\
\hline Iron (Fe) & $16.86^{a}$ & $12.65 d^{e}$ & $11.88^{\mathrm{e}}$ & $13.56^{\mathrm{cd}}$ & $14.3^{c}$ & $15.65^{b}$ \\
\hline Manganese (Mn) & $15.50^{\mathrm{a}}$ & $9.35^{\mathrm{bc}}$ & $8.39^{c}$ & $7.13^{d}$ & $9.57^{b}$ & $10.21^{b}$ \\
\hline Zinc (Zn) & $5.84^{\mathrm{a}}$ & $5.52^{\mathrm{a}}$ & $3.75^{b}$ & $2.97^{c}$ & $6.07^{a}$ & $6.07^{a}$ \\
\hline Copper (Cu) & $3.94^{b}$ & $3.77^{\mathrm{b}}$ & $3.26^{\mathrm{bc}}$ & $2.44^{c}$ & $3.08^{b c}$ & $3.08^{a}$ \\
\hline
\end{tabular}

* sweet melon 1 Cucumis melo var. reticulatus

** sweet melon 2 Cucumis melo var. aegyptiacus

* The values in the table are means of the triplicates \pm SD 


\section{Physicochemical properties of cucurbits seeds oil}

The physicochemical properties of cucurbits seeds oil are presented in (Table 3). The Refractive index ranged from (1.4624 to 1.4294), which is nearly the same value of volatile oil. Saponification value $(227.6$ to $189.6 \mathrm{mg}$ of $\mathrm{KOH} / \mathrm{g}$ of oil), this result revealed that the saponification value mostly the same as commercial vegetable oil. lodine value (105.08 to $82.09 \mathrm{~g}$ of $\mathrm{I}_{2} / 100 \mathrm{~g}$ of oil), peroxide value (2.2 to 10.1 Equiv. of $\mathrm{O}_{2} / \mathrm{kg}$ of oil) free fatty acid $(0.21$ to $0.49 \%$ as oleic acid). Regarding the refractive index, the data showed that all the studied samples had nearly the same value as vegetable oils and the data of refractive index confirming the iodine value for each cultivar, the data in Table (3) showed that there is a positive correlation between iodine value and refractive index.

The result presented in the current study is in agreement with (Nyam et al., 2009) who reported that melon seeds peroxide value (2.3 Equiv. of $\mathrm{O}_{2} / \mathrm{kg}$ of oil), acid value (1.1 mg of $\mathrm{KOH} / \mathrm{g}$ of oil), saponification value $(173.2 \mathrm{mg}$ of $\mathrm{KOH} / \mathrm{g}$ of oil), iodine value (125.0 g of $\mathrm{I}_{2} / 100 \mathrm{~g}$ of oil), and (Kamel et al., 1985) who reported that melon seeds oil peroxide value (7.9 Equiv of $\mathrm{O}_{2} / \mathrm{kg}$ of oil), acid value $(0.97 \mathrm{mg}$ of $\mathrm{KOH} / \mathrm{g}$ of oil), saponification value $(248 \mathrm{mg}$ of $\mathrm{KOH} / \mathrm{g}$ of oil), iodine value (116 $\mathrm{g}$ of $\mathrm{I}_{2} / 100 \mathrm{~g}$ of oil). On the other hand the obtained values lower than that shown by (Oyeleke et al., 2012) who reported that Watermelon (Citrullus lanatus) seeds oil showed a peroxide value (2.8 Equiv of $\mathrm{O}_{2} / \mathrm{kg}$ of oil), acid value (3.4 $\mathrm{mg}$ of $\mathrm{KOH} / \mathrm{g}$ of oil), saponification value $(148.5 \mathrm{mg}$ of $\mathrm{KOH} / \mathrm{g}$ of oil), iodine value ( $74.5 \mathrm{~g}$ of $\mathrm{I}_{2} / 100 \mathrm{~g}$ of oil) and (Sawaya et al., 1983) who reported that (Citrullus lanatus var. Colocynthoides) seeds oil show peroxide value (3 Equiv. of $\mathrm{O}_{2} / \mathrm{kg}$ of oil), acid value $(0.84 \mathrm{mg}$ of $\mathrm{KOH} / \mathrm{g}$ of oil), saponification value (207.9 $\mathrm{mg}$ of $\mathrm{KOH} / \mathrm{g}$ of oil), iodine value $\left(90.85 \mathrm{~g}\right.$ of $\mathrm{I}_{2} / 100 \mathrm{~g}$ of oil). While Compatible with (Alfawaz, 2004) who reported that pumpkin seeds oil showed a peroxide value ( 0.85 Equiv. of $\mathrm{O}_{2} / \mathrm{kg}$ of oil), acid value $(0.53 \mathrm{mg}$ of $\mathrm{KOH} / \mathrm{g}$ of oil), saponification value (185.2 $\mathrm{mg}$ of $\mathrm{KOH} / \mathrm{g}$ of oil), iodine value (105.12 $\mathrm{g}$ of $\mathrm{I}_{2} / 100 \mathrm{~g}$ of oil), while (Gohari et al., 2011) reported that Cucurbita pepo seeds oil showed peroxide value (10.85 Equiv. of $\mathrm{O}_{2} / \mathrm{kg}$ of oil), acid value ( $0.78 \mathrm{mg}$ of $\mathrm{KOH} / \mathrm{g}$ of oil), saponification value $(190.6 \mathrm{mg}$ of $\mathrm{KOH} / \mathrm{g}$ of oil), iodine value ( $104.3 \mathrm{~g}$ of $\mathrm{I}_{2} / 100 \mathrm{~g}$ of oil). 
Table (3): Physicochemical properties of cucurbit's seeds oil

\begin{tabular}{|c|c|c|c|c|c|c|}
\hline \multirow{2}{*}{ Properties } & \multicolumn{6}{|c|}{ Cucurbits seeds } \\
\hline & sweet melon 1 * & sweet melon $2^{* *}$ & watermelon & citron melon & Pumpkin & summer squash \\
\hline $\begin{array}{l}\text { refractive index (25 } \\
\left.{ }^{\circ} \mathrm{C}\right)\end{array}$ & $1.4461^{b}$ & $1.4589^{b}$ & $1.4413^{b c}$ & $1.4477^{\mathrm{bc}}$ & $1.4294^{d}$ & $1.4624^{a}$ \\
\hline $\begin{array}{l}\text { saponification value } \\
\text { ( } \mathrm{mg} \text { of } \mathrm{KOH} / \mathrm{g} \text { of oil) }\end{array}$ & $189.6^{\mathrm{e}}$ & $216.0^{\mathrm{b}}$ & $214.2^{c}$ & $207.9^{d}$ & $182.6^{f}$ & $227.6^{\mathrm{a}}$ \\
\hline $\begin{array}{l}\text { iodine value ( } \mathrm{g} \text { of } \\
\mathrm{I}_{2} / 100 \mathrm{~g} \text { of oil) }\end{array}$ & $105.08^{a}$ & $97.85^{\mathrm{C}}$ & $82.09^{f}$ & $90.85^{d}$ & $89.3^{\mathrm{e}}$ & $101.6^{b}$ \\
\hline $\begin{array}{l}\text { peroxide value } \\
\text { (mequiv of } 02 / \mathrm{kg} \text { of } \\
\text { oil) }\end{array}$ & $6.6^{b}$ & $4.2^{c}$ & $2.2^{d}$ & $3.1^{d}$ & $7.2^{b}$ & $10.1^{a}$ \\
\hline $\begin{array}{l}\text { free fatty acid } \% \text { (\% } \\
\text { as oleic acid) }\end{array}$ & $0.31^{b}$ & $0.35^{\mathrm{b}}$ & $0.49^{a}$ & $0.42^{a}$ & $0.42^{a}$ & $0.21^{\mathrm{c}}$ \\
\hline
\end{tabular}

* sweet melon 1 Cucumis melo var. reticulatus

** sweet melon 2 Cucumis melo var. aegyptiacus

* The values in the table are means of the triplicates \pm SD 


\section{Functional properties of cucurbits seeds (defatted powder)}

Functional properties are important in determining quality as they give information on how food ingredients will behave in a food system. The functional properties of cucurbits seeds were presented in Table (4) Bulk density ranged from

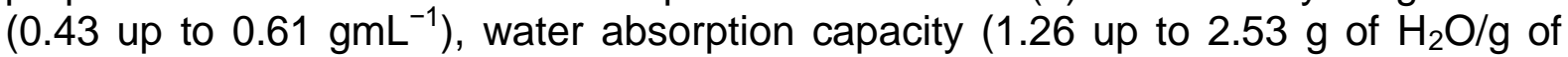
flour), oil absorption capacity (1.34up to $2.17 \mathrm{~g}$ of oil $/ \mathrm{g}$ of flour), emulsion capacity (12.0 up to $32.0 \%$ ), foam capacity (8.52 up to $15.96 \%$ ), and good foam stability, The highest content of bulk density was noted in sweet melon Cucumis melo var. reticulatus $\left(0.61 \pm 0.01^{\mathrm{b}} \mathrm{gmL}-1\right)$. The highest content of water absorption capacity was summer squash $\left(2.53 \mathrm{~g}\right.$ of $\mathrm{H}_{2} \mathrm{O} / \mathrm{g}$ of flour), The highest content of oil absorption capacity and foam capacity was pumpkin $(2.17 \mathrm{~g}$ of oil $/ \mathrm{g}$ of flour), (15.96\%) respectively.

The results presented in the current study are slightly lower than the result reported by (Mallek-Ayadi et al., 2018) and (Mallek-Ayadi et al., 2019) who reported that melon seeds show bulk density $\left(0.65 \mathrm{gmL}^{-1}\right)$, water absorption capacity(2.33g of $\mathrm{H}_{2} \mathrm{O} / \mathrm{g}$ of flour), oil absorption capacity $(2.59 \mathrm{~mL}$ of oil/g of flour), emulsion capacity $(30.0 \mathrm{~mL}$ of oil/g of protein), foam capacity (19.9\% vol increase). The results of the present study agreed with (El-Adawy and Taha, 2001b) who reported that watermelon seeds show water absorption capacity $\left(2.55 \mathrm{~g} \mathrm{of} \mathrm{H}_{2} \mathrm{O} / \mathrm{g}\right.$ of flour), oil absorption capacity $(3.89 \mathrm{~mL}$ of oil/g of flour), emulsion capacity $(98.2 \mathrm{~mL}$ of $\mathrm{oil} / \mathrm{g}$ of flour), foam capacity ( $18.12 \%$ vol increase). The results presented in this investigation are slightly lower than the result reported by (El-Adawy and Taha, $2001 \mathrm{~b})$ who reported that pumpkin seeds show water absorption capacity $(2.51 \mathrm{~g}$ of $\mathrm{H} 2 \mathrm{O} / \mathrm{g}$ of flour), oil absorption capacity $(3.85 \mathrm{~mL}$ of oil/g of flour), emulsion capacity $(98.5 \mathrm{~mL}$ of oil/g of flour), foam capacity $(18.65 \%$ vol increase).

\section{Conclusion}

The seeds of the cucurbit varieties in Egypt exhibited a converging chemical composition. They consist of a comparatively high amount of oil (27.38-39.1\%), protein (20.1-40.1\%), fiber (12.0-29.0\%), and minerals that determine their high nutritional value. The obtained oils have good physicochemical properties such as vegetable oils. From the highlights of the present study, we can deduce that these seeds may serve as constituents for protein, oil, ash, and fiber in food products. 
Table (4): functional properties for cucurbits seeds flour

\begin{tabular}{|c|c|c|c|c|c|c|}
\hline \multirow{2}{*}{ Functional properties } & \multicolumn{6}{|c|}{ Cucurbits seeds } \\
\hline & sweet melon 1 * & sweet melon $2^{\star \star}$ & watermelon & citron melon & Pumpkin & summer squash \\
\hline Bulk density (gmL-1) & $0.61 \pm 0.01^{b}$ & $0.51 \pm 0.02^{b}$ & $0.51 \pm 0.05^{b}$ & $0.45 \pm 0.03^{c}$ & $0.46 \pm 0.03^{c}$ & $0.43 \pm 0.05 d$ \\
\hline $\begin{array}{l}\text { Water absorption } \\
\text { capacity }\left(\mathrm{g} \text { of } \mathrm{H}_{2} \mathrm{O} / \mathrm{g} \text { of }\right. \\
\text { flour) }\end{array}$ & $1.87 \pm 0.02^{c}$ & $1.78 \pm 0.03^{d}$ & $1.76 \pm 0.01^{d}$ & $1.26 \pm 0.03^{\mathrm{e}}$ & $2.36 \pm 0.04^{b}$ & $2.53 \pm 0.02 \mathrm{a}$ \\
\hline $\begin{array}{l}\text { Oil absorption } \\
\text { capacity (mL of oil/g of } \\
\text { flour) }\end{array}$ & $1.36 \pm 0.01^{d}$ & $1.37 \pm 0.04^{d}$ & $1.86 \pm 0.03^{b}$ & $1.34 \pm 0.06^{\mathrm{e}}$ & $2.17 \pm 0.01^{\mathrm{a}}$ & $1.66 \pm 0.05 c$ \\
\hline Emulsion capacity (\%) & $13.0 \pm 0.04^{\mathrm{e}}$ & $12.0 \pm 0.02^{f}$ & $32.0 \pm 0.02^{\mathrm{a}}$ & $30.0 \pm 0.04^{b}$ & $28.0 \pm 0.07^{c}$ & $20.0 \pm 0.04 d$ \\
\hline $\begin{array}{l}\text { Foam capacity } \\
\text { (\% vol increase) }\end{array}$ & $13.04 \pm 0.11^{d}$ & $11.5 \pm 0.02^{e}$ & $14.5 \pm 0.04^{b}$ & $8.52 \pm 0.01^{f}$ & $15.96 \pm 0.02 a$ & $13.79 \pm 0.03 c$ \\
\hline \multicolumn{7}{|l|}{ Foaming stability $(\mathrm{mL})$ at } \\
\hline $15 \mathrm{~min}$ & $59.81 \pm 0.14^{\mathrm{e}}$ & $53.82 \pm 0.1^{\dagger}$ & $70.59 \pm 0.06^{d}$ & $96.96 \pm 0.19^{a}$ & $84.2 \pm 0.2^{c}$ & $94.27 \pm 0.09^{b}$ \\
\hline $30 \mathrm{~min}$ & $52.91 \pm 0.06^{\dagger}$ & $53.82 \pm 0.11^{\mathrm{e}}$ & $70.59 \pm 0.14^{d}$ & $96.96 \pm 0.21^{a}$ & $84.2 \pm 0.16^{c}$ & $87.45 \pm 0.1^{\mathrm{b}}$ \\
\hline $45 \mathrm{~min}$ & $52.91 \pm 0.12^{f}$ & $53.82 \pm 0.05^{\mathrm{e}}$ & $70.59 \pm 0.23^{c}$ & $88.48 \pm 0.07^{\mathrm{a}}$ & $73.68 \pm 0.08^{b}$ & $62.5 \pm 0.17^{d}$ \\
\hline $60 \mathrm{~min}$ & $39.87 \pm 0.03^{f}$ & $45.21 \pm 0.13^{\mathrm{e}}$ & $64.73 \pm 0.07^{c}$ & $66.6 \pm 0.1^{\mathrm{b}}$ & $73.68 \pm 0.11^{\mathrm{a}}$ & $49.96 \pm 0.03^{d}$ \\
\hline
\end{tabular}

*sweet melon 1 Cucumis melo var. reticulatus

**sweet melon 2 Cucumis melo var. aegyptiacus

* The values in the table are means of the triplicates 


\section{REFERENCES:}

AL-KHALIFA, A. 1996. Physicochemical characteristics, fatty acid composition, and lipoxygenase activity of crude pumpkin and melon seed oils. Journal of Agricultural and Food Chemistry, 44, 964-966.

ALFAWAZ, M. A. 2004. Chemical composition and oil characteristics of pumpkin (Cucurbita maxima) seed kernels. Food Science and Agriculture, 2, 5-18.

AOAC 2000. The use of inductively coupled plasma mass spectrometry (ICPMS) for the determination of toxic and essential elements in different types of food samples. Food Chemistry, 112(3), 727-732.

BAWA, A. \& BAINS, G. 1977. Integrated processing of watermelons for juice and seed. Indian food packer.

CARRAPISO, A. I. \& GARCÍA, C. 2000. Development in lipid analysis: some new extraction techniques and in situ transesterification. Lipids, 35, 1167-1177.

DA CUNHA, J. A., ROLIM, P. M. \& DA SILVA CHAVES, K. S. F. 2020. From seed to flour: sowing sustainability in the use of cantaloupe melon residue (Cucumis melo L. var. reticulatus). PloS one, 15.

DA SILVA, A. C. \& JORGE, N. 2014. Bioactive compounds of the lipid fractions of agro-industrial waste. Food Research International, 66, 493-500.

EL-ADAWY, T. A. \& TAHA, K. M. 2001a. Characteristics and composition of different seed oils and flours. Food chemistry, 74, 47-54.

EL-ADAWY, T. A. \& TAHA, K. M. 2001b. Characteristics and composition of watermelon, pumpkin, and paprika seed oils and flours. Journal of agricultural and food chemistry, 49, 1253-1259.

ELINGE, C., MUHAMMAD, A., ATIKU, F., ITODO, A., PENI, I., SANNI, O. \& MBONGO, A. 2012. Proximate, mineral and anti-nutrient composition of pumpkin (Cucurbitapepo L) seeds extract. International Journal of plant research, 2, 146-150.

ELTAYEBL, M. M. \& BABIKER, E. E. 2008. Nutritional evaluation and physiochemical properties of processed pumpkin (Telfairia occidentalis Hook) seed flour. Pakistan Journal of Nutrition, 7, 330-334.

FAOSTAT, F. 2015. Agriculture Organization of the United Nations, 2011. FAO, Retrieved am from http://faostat3. fao. org/faostatgateway/go/to/download/Q/QC/S. Acceso, 20.

GARAU, M. C., SIMAL, S., ROSSELLO, C. \& FEMENIA, A. 2007. Effect of airdrying temperature on physico-chemical properties of dietary fibre and antioxidant capacity of orange (Citrus aurantium v. Canoneta) byproducts. Food chemistry, 104, 1014-1024.

GIRGIS, P. \& SAID, F. 1968. Lesser known Nigerian edible oils and fats. 1. Characteristics of melon seed oils. Journal of the Science of Food and Agriculture, 19, 615-616.

GOHARI, ARDABILI A FARHOOSH, REZA HADDAD \& MH, K. 2011. Chemical composition and physicochemical properties of pumpkin seeds (Cucurbita pepo Subsp. pepo Var. Styriaka) grown in Iran.

GONG, L., PARIS, H. S., NEE, M. H., STIFT, G., PACHNER, M., VOLLMANN, J. \& LELLEY, T. 2012. Genetic relationships and evolution in Cucurbita pepo (pumpkin, squash, gourd) as revealed by simple sequence repeat polymorphisms. Theoretical and Applied Genetics, 124, 875-891. 
GWANA, A., BAKO, M., BAGUDU, B., SADIQ, A. \& ABDULLAHI, M. M. 2014. Determinations of phytochemical, vitamin, mineral and proximate compositions of varieties of watermelon seeds cultivated in Borno State, North-Eastern Nigeria. International Journal of Nutrition and food sciences, 3, 238-245.

HASAN, F. 1993. Research on the possibility of using watermelon juice in the fruit juice cocktails. Gida, 18, 369-371.

HORWITZ, W. \& ALBERT, R. 2006. The Horwitz ratio (HorRat): a useful index of method performance with respect to precision. Journal of AOAC International, 89, 1095-1109.

KAMEL, B. S., DAWSON, H. \& KAKUDA, Y. 1985. Characteristics and composition of melon and grape seed oils and cakes. Journal of the American Oil Chemists' Society, 62, 881-883.

KARRAR, E., SHETH, S., WEI, W. \& WANG, X. 2020. Effect of microwave heating on lipid composition, oxidative stability, color value, chemical properties, and antioxidant activity of gurum (Citrulluslanatus var. Colocynthoide) seed oil. Biocatalysis and Agricultural Biotechnology, 23, 101504.

KAUR, M. \& SINGH, N. 2005. Studies on functional, thermal and pasting properties of flours from different chickpea (Cicer arietinum L.) cultivars. Food chemistry, 91, 403-411.

KAUSHIK, U., AERI, V. \& MIR, S. R. 2015. Cucurbitacins-an insight into medicinal leads from nature. Pharmacognosy reviews, 9, 12.

LIMA, B., LIMA, F., TAVARES, M., COSTA, A. \& PIERUCCI, A. 2014. Determination of the centesimal composition and characterization of flours from fruit seeds. Food chemistry, 151, 293-299.

MALLEK-AYADI, S., BAHLOUL, N. \& KECHAOU, N. 2018. Chemical composition and bioactive compounds of Cucumis melo L. seeds: Potential source for new trends of plant oils. Process Safety and Environmental Protection, 113, 68-77.

MALLEK-AYADI, S., BAHLOUL, N. \& KECHAOU, N. 2019. Phytochemical profile, nutraceutical potential and functional properties of Cucumis melo

L. seeds. Journal of the Science of Food and Agriculture, 99, 1294-1301.

MARAN, J. P. \& PRIYA, B. 2015. Supercritical fluid extraction of oil from muskmelon (Cucumis melo) seeds. Journal of the Taiwan Institute of Chemical Engineers, 47, 71-78.

NARAYANA, K. \& NARASINGA RAO, M. 1982. Functional properties of raw and heat processed winged bean (Psophocarpus tetragonolobus) flour. Journal of food science, 47, 1534-1538.

NARDI, E. P., EVANGELISTA, F. S., TORMEN, L., SAINT, T. D., CURTIUS, A. J., DE SOUZA, S. S. \& BARBOSA JR, F. 2009. The use of inductively coupled plasma mass spectrometry (ICP-MS) for the determination of toxic and essential elements in different types of food samples. Food Chemistry, 112, 727-732.

NYAM, K. L., TAN, C. P., CHE MAN, Y. B., LAI, O. M. \& LONG, K. 2009. Physicochemical properties of Kalahari melon seed oil following extractions using solvent and aqueous enzymatic methods. International journal of food science \& technology, 44, 694-701. 
OLUWADARE, I., OLAWUNMI, M. \& TAIWO, A. 2008. EFFECTS OF DRYING METHODS ON PROPERTIES OF WATER MELON (Citrullus lanatus) SEED OIL.

ORTIZ, J., ROMERO, N., ROBERT, P., ARAYA, J., LOPEZ-HERNÁNDEZ, J., BOZZO, C., NAVARRETE, E., OSORIO, A. \& RIOS, A. 2006. Dietary fiber, amino acid, fatty acid and tocopherol contents of the edible seaweeds Ulva lactuca and Durvillaea antarctica. Food chemistry, 99, 98-104.

OYELEKE, G., OLAGUNJU, E. \& OJO, A. 2012. Functional and physicochemical properties of watermelon Citrullus Lanatus seed and seed-oil. Journal of Applied Chemistry, 2, 29-31.

REZIG, L., CHOUAIBI, M., MEDDEB, W., MSAADA, K. \& HAMDI, S. 2019. Chemical composition and bioactive compounds of Cucurbitaceae seeds: Potential sources for new trends of plant oils. Process Safety and Environmental Protection, 127, 73-81.

RIAZ, H., CHATHA, S. A. S., HUSSAIN, A. I., BUKHARI, S. A., HUSSAIN, S. M. \& ZAFAR, K. 2015. Physico-chemical characterization of bitter apple (Citrullus colosynthis) seed oil and seed residue. Int. J. Biosci, 6, 283292.

SAWAYA, W., DAGHIR, N. \& KHAN, P. 1983. Chemical characterization and edibility of the oil extracted from Citrullus colocynthis seeds. Journal of Food Science, 48, 104-106.

WALKER, R. 1980. Official and Tentative Methods of the American Oil Chemists' Society. American Oil Chemists' Society, Champaign, IL.

YASUMATSU, K., SAWADA, K., MORITAKA, S., MISAKI, M., TODA, J., WADA, T. \& ISHII, K. 1972. Whipping and emulsifying properties of soybean products. Agricultural and Biological Chemistry, 36, 719-727.

ZEB, A. 2016. Phenolic Profile and Antioxidant Activity of Melon (Cucumis Melo L.) Seeds from Pakistan. Foods, 5, 67. 


\section{الملخص العربي}

\section{التركيب الكيماوي والخصائص الفيزيائية لبعض بذور وزيوت القرعيات المصرية}

حسن جمال فتح الله 'صبحى احمد السحيمى 2,3 أشرف عبدالمنعم زيتون ' محمد عبدالحميد إسماعيل '

$$
\text { 1- قسم علوم الأغذية -كلية الزراعة (سابا باشا) - جامعة الإسكندرية - الإسكندرية - مصر }
$$

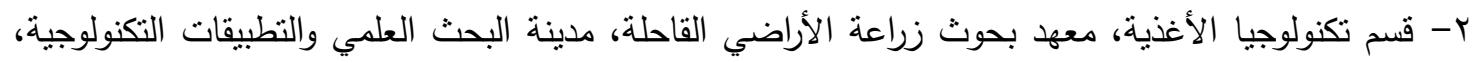

الإسكندرية، مصر

r- ق قسم التكنولوجيا وتتظيم خدمات المطاعم العامة، معهد السياحة والخدمات الرياضية

تتكون العائلة القرعية Cucurbitaceae من · با جنس و . .1 نوع، بما في ذلك الكانتلوب وقرع الكوسة

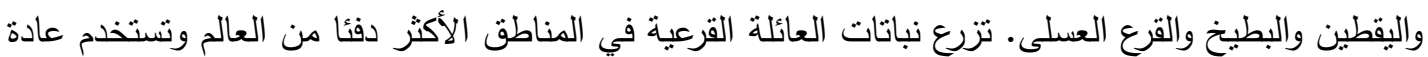
العديد من أجزائها كغذاء، وخاصة الثمار والزهور ، والبذور ومع ذللك، تستخدم بذور القرعيات منذ فترة طويلة


الهدف من هذه الدراسة هو تقييم التركيب الكيميائي، والقيمة الغذائية، والخصائص الوظيفية لبعض بذور العائلة القرعية وكذلك خواص الزيوت الناتجة منها. وأوضحت النتائج المتحصل عليها ان البذور غنية بالبروتين والدهون الخام والألياف الخام. حيث تراوحت نسبة الدهون الخام بين (27.3 إلى 39.1\%ة)، وتراوحت نسبة الألياف الخام من (r الى 29\%)، وتراوحت نسبة البروتينات من (20.1 إلى 40.1\%)؛

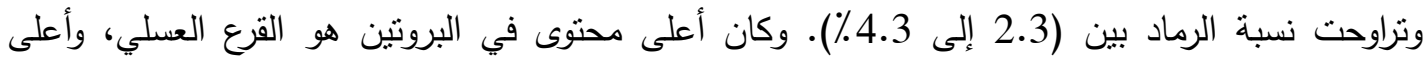

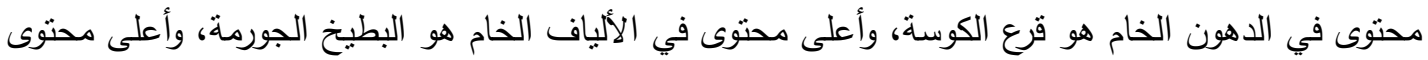

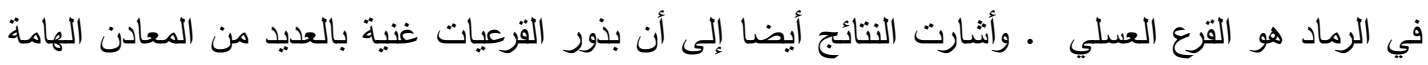

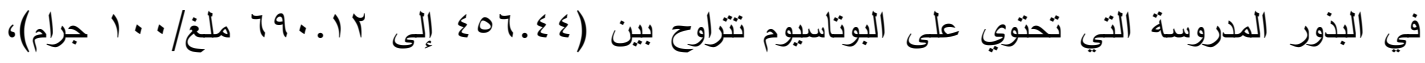

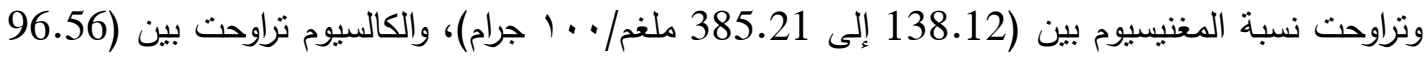

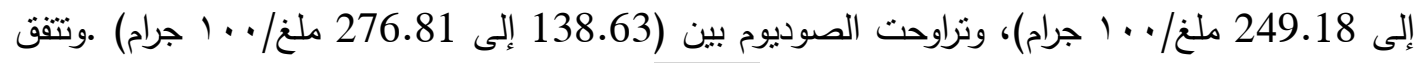
البيانات التي تم الحصول عليها بشأن خصائص الزيوت بشكل جيد مع الزيوت النباتية الصالحة للأكل

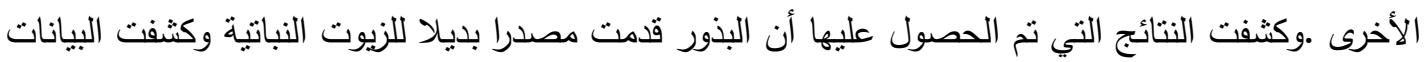
التي نم الحصول عليها أيضا أن بذور القرعيات لها خصائص وظيفية جيدة. وكان البطيخ الحلو melo var reticulatust.

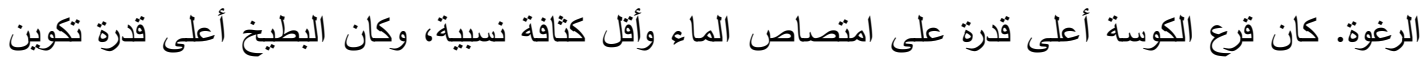
مستحلب وتكوين الرغوة. وبذلك يمكن ان تستخدم هذه البذور كمصدر جيد لكل من البروتين والزيت والالياف والاملاح المعدنية في منتجات الأغذية. 
